\title{
SYARAT KESIHATAN FIZIKAL BAGI KETUA NEGARA: ANALISIS HUKUM DAN REALITI POLITIK DI INDONESIA
}

\section{Physical Health Requirement for the Head of A State: Legal Analysis and Political Reality in Indonesia}

\author{
Abdul Halim Harun ${ }^{1}$ \\ Sharifah Hayaati Syed Ismail al-Qudsy ${ }^{2}$
}

\begin{abstract}
This article is a qualitative study using library research and related documents, analyzed using the descriptive method. The study found that the majority of scholars list the physical health requirements for a head of state as salāmah al-hawās wa al-a'd̄a (mentally and physically healthy) or kifāyah al-ajsām (perfect body). This indicates their agreement on the importance of health requirements for candidates for head of state. However, some scholars do not list health as a requirement, considering it unimportant, because what is important is that the head of state has leadership capability and intellectual intelligence. Therefore, health is considered by some scholars to be a requirement whose
\end{abstract}

\footnotetext{
Postgraduate Student, Department of Siasah Syar'iyyah, Academy of Islamic Studies, University of Malaya, 50603 Kuala Lumpur, liem234@gmail.com

2 Associate Professor, Department of Siasah Syar'iyyah, Academy of Islamic Studies, University of Malaya, 50603 Kuala Lumpur, sashsiaq@um.edu.my
} 
suitability is disputed while some scholars put it as a requirement for completeness. This difference in opinion has created an opportunity to review the situation and obtain the best opinion based on the needs and realities of local politics. In the current context, a health requirement has become a necessity in some countries, imposed by an Act or the Constitution, for example The Republic of Indonesia under Law No. 23 of the Presidential Election 2003, Article 6 (d). ${ }^{3}$ Therefore, this article aims to analyse the views of scholars, current views and the provisions for policy implementation in Indonesia to produce appropriate physical health requirements for the head of state which can be applied without violating Islamic law.

Keywords: physical health requirement, head of state, political ijtihād, Indonesia

\section{PENDAHULUAN}

Perlantikan ketua negara merupakan satu perkara yang wajib dilaksanakan di dalam sesebuah negara yang berdaulat. Pandangan itu telah dikemukakan oleh jumhur fuqaha seperti, al-Māwardī, ${ }^{4}$ Ibnu Khaldūn, ${ }^{5}$ al-Shawkān̄̄, ${ }^{6}$ alAsh'ari, ${ }^{7}$ al-Qurțub $\overline{1},{ }^{8}$ al-Ghazāli ${ }^{9}$ dan banyak lagi ulama Ahli Sunnah yang

3 Undang-Undang Pilihan Raya Presiden No. 23 Tahun 2003 adalah undang-undang yang secara tidak langsung telah menggagalkan pencalonan Gus Dur sebagai calon Presiden pada tahun 2004, dan undang-undang tersebut kini telah dipinda menjadi Undang-Undang Pilihan Raya Presiden No. 42 Tahun 2008, tetapi isi kandungan yang berkaitan dengan syarat kesihatan fizikal tidak mengalami sebarang apa-apa perubahan.

4 Abū Hasan 'Alī bin Muhammad bin Habīb al-Bașri al-Māwardi, al-Aḥām alSulțāniyah wa al-Wilayāt al-Dīniyyah, taḥqīq, Dr. Aḥmad Mubārak al-Baghdādi (Kuwayt: Maktabah Dār Ibn Qutaybah, 1989), 3.

5 'Abd al-Raḥmān bin Khaldūn, Muqaddimah Ibn Khaldūn: al-Musammā bì alKitāb al-'Ibar wa al-'Ajam wa al-Barbar wa Man 'Asrāruhum min Daw'i alSulțān al-Akhbār (Beirūt: Dār al-Kutub al-'Ilmiyyah, 2003), 151.

6 Muhammad bin 'Alī bin Muḥammad al-Shawkānī, Nayl al-Awṭār Sharh Muntaqā al-Akhbār, vol. 8 (Miṣr: Maktabah wa Mațba’ah Mușțafā al-Bābī al-Ḥalabī wa Awlāduh, t.t.), 288.

7 Abū al-Hasan 'Alī bin Ismā‘n̄l al-'Ash'āri, Maqālāt al-Islāmiyyīn wa al-Ikhtilāf al-Mușallīn, vol. 2 (Beirūt: Maktabah al-'Așriyyah, 1990), 149.

$8 \quad$ Abī 'Abdillah Muhammad bin Aḥmad bin Ab̄̄ Bakr al-Qurtubī, al-Jāmi ‘ lì Ahkām al-Qur'ān, vol. 1, taḥqiq, Dr. 'Ảbd Allāh bin 'Abd al-Muhsin al-Turkī (Beirūt: Mu'assasah al-Risālah, 2006), 296.

9 Abī Ḥāmid Muḥammad bin Muḥammad bin Muḥammad al-Ghazāli, al-Iqtiṣād wa 
lainnya. Malahan pandangan tersebut juga sejalan dengan golongan Murji'ah dan Syi'ah, serta majoriti ulama Mu'tazilah dan Khawarij. ${ }^{10}$ Oleh yang demikian, maka seseorang yang akan menjawat ketua negara mestilah orang yang telah memenuhi beberapa kriteria tertentu yang telah ditentukan dalam al-Quran dan al-Hadith al-Nabawi. Kriteria atau syarat-syarat ketua negara telah dirumuskan oleh majoriti para ulama antaranya ialah syarat kesihatan fizikal atau sempurna anggota badan dan sihat panca indera, seperti hilang pendengaran, penglihatan dan pertuturan. Syarat tersebut dalam konteks kepimpinan hari ini masih dianggap sesuai oleh sesetengah negara, seperti negara Republik Indonesia yang mempunyai peruntukan dalam undang-undang khas pilihan raya Presiden No. 23 Tahun 2003. Isu ini timbul dan menjadi polemik dalam pelbagai kalangan masyarakat ketika Parti Kebangkitan Bangsa (PKB) mencalonkan Abdurrahman Wahid atau Gus Dur yang cacat penglihatan menjadi ketua negara atau Presiden pada tahun 2004. Artikel ini secara amnya terdiri daripada lima bahagian iaitu A - E yang meliputi pembahasan tentang pandangan ulama terhadap syarat kesihatan fizikal ketua negara, pandangan semasa tentang syarat kesihatan ketua negara, peruntukan undang-undang dan isu syarat kesihatan ketua negara di Indonesia, hasil kajian literatur berkaitan konsep syarat kesihatan fizikal bagi ketua negara, hasil kajian literatur berkaitan pemakaian syarat kesihatan fizikal bagi ketua negara di Indonesia, dan diakhiri dengan kesimpulan berkaitan pandangan yang terbaik dan sesuai bagi syarat kesihatan ketua negara di Indonesia.

\section{PANDANGAN ULAMA TENTANG SYARAT KESIHATAN FIZIKAL KETUA NEGARA}

Hasil kajian daripada beberapa pandangan ulama dalam bidang kepimpinan dan kenegaraan, seperti Ibnu Taymiyyah (1262-1328 M) dalam kitabnya alSiyāsah al-Shar 'iyyah, Imām al-Māward̄̄ (975-1059 M) dalam al-Aḥkām al-Sulțāniyyah wa al-Wilayāt al-Dīniyyah, Abū Ya'lā (1059-1131 M) dalam al-Ahkām al-Sulțāniyyah, Imām al-Haramayn (1028-1087 M) dalam Ghiyāth al-Umamfíal-Tiyàth al-Zulam, Hasan Ismā'īl al-Hudaybīi(1891-1973 M) dalam kitab Du 'āt la Quḍ̄àt, al-Mawdūdī (1903-1979 M) al-Sharī'ah wa al-Qanūn, Abū Fāris (1940 M) dalam al-Qāḍ̄ Abū Ya lā al-Farrā wa Kitābuh al-Aḥkām al-Sulțāniyyah dan al-Rayis (1912-1977 M) dalam al-Nazariyāt al-Siyāsiyyah al-Islāmiyyah mendapati bahawa majoriti ulama fiqh berpandangan bahawa syarat kesihatan fizikal bagi ketua negara adalah merupakan salah satu syarat

al-I 'tiqād (Dimasq: al-Ḥikmah L̄̄ al-Ṭibā'ah wa al-Nashr, 1994), 200.

10 Abū Muḥammad 'Alī bin Aḥmad Ibn Hazm al-Ẓāhirī, al-Faṣl fì al-Milal wa alAhwā wa al-Nihal, vol. 4 (Beirūt: Dār al-Jayl, 1996), 149. 
utama yang mesti dipenuhi oleh calon ketua negara. Justifikasi pandangan tersebut adalah berdasarkan kepada pentingnya kedudukan dan peranan ketua negara sebagai seorang yang mempunyai kedudukan yang tinggi bagi menjalankan tugas dan amanah untuk mentadbir dan mengendalikan urusan dunia sesuai dengan syariat Allah SWT.

Oleh yang demikian, maka para ulama telah memberikan beberapa persyaratan antaranya ialah syarat kesihatan fizikal. Maksud kesihatan fizikal menurut para ulama ialah sejahtera (sihat) panca indera dan sempurna anggota badan dari kecacatan yang boleh mendatangkan kesan terhadap cara berfikir dan bekerja. Selain kecacatan yang membawa kesan kepada kecergasan dan ketangkasan ketua negara dalam mentadbir negara, sehingga mengakibatkan hilang keupayaan dan kurang kewibawaan di sisi rakyat. ${ }^{11}$ Istilah syarat kesihatan fizikal yang digunakan oleh kebanyakan para ulama ialah salāmah al-ḥawās wa al-a 'ḍ̄ (sejahtera atau sihat panca indera dan anggota badan). Manakala istilah lain yang juga digunakan misalnya oleh Muhammad Ra'fat Uthmān menggunakan al-kifāyah al-jismiyyah (sempurna anggota badan), ${ }^{12}$ Ibn Abī al-Rab'i' menggunakan șahīh al-a'da (sihat anggota badan) dan 'Ali 'Abd al-Wahid Wafi ${ }^{14}$ menggunakan tām al-a' $d \bar{a}$ (sempurna anggota badan).

Walau demikian, terdapat golongan yang tidak mementingkan syarat tersebut menjadi satu kemestian pada diri seseorang calon yang akan menjadi ketua negara seperti Ibn Hazm, ${ }^{15}$ Abū Tayyib Ābādî ${ }^{16}$ dan al-Khattāâi. ${ }^{17}$ Ini kerana mereka berpandangan bahawa perkara tersebut bertentangan dengan hak asasi manusia yang telah digariskan di dalam Syariah, dan seseorang yang sihat jasmani atau secara fizikal belum tentu orang tersebut sihat secara rohani, kerana syarat utama terpilihnya ketua negara ialah sokongan politik daripada rakyat. Malah menurut pandangan radikal Ibn Hazm kelayakan calon ketua

11 'Abd Allāh bin 'Umar bin Sulaymān al-Damījī, al-Imāmah al- 'Użmā 'Inda Ahli al-Sunnah wa al-Jamā' 'ah (Riyāụ: Dār al-Ṭayyibah, 1987), 261.

12 Muhammad Ra'fat 'Uthmān, Riyāsah al-Dawlah fì al-Fiqh al-Islāmī (Qāhirah: Dār al-Kitāb al-Jami‘’̄, 1975), 167.

13 Shihab al-Dīn Aḥmad bin Muhammad Ibn Abī al-Rabi', Suluk al-Malik fī Tadbīr al-Mamalik, tahqiq, 'Arif Aḥmad Abdul Ghani (Syiria: Dār Kannan, 1996), 39.

14 'Alī 'Abd al-Wāhid Wafî, al-Madīnah al-Fadilah li al-Farabi (Qāhirah: Nahụah Misr, t.t.), 69-70.

15 al-Imām Abī Muhammad 'Alī bin Aḥmad Ibn Ḥazmi al-Ẓāhirī, al-Faṣl fí al-Milal wa al-Ahwā wa al-Niḥl, vol. 5, taḥīq, Muhammad Ibrāhīm Naṣr et al. (Beirūt: Dār al-Jayl, 1996), 11.

16 Abū Ṭayyib Muhammad Shamsu al-Ḥaq al-'Az̄̄m Ābādiyy, 'Awnu al-Ma 'būd, vol. 8, taḥqīq, 'Abd al-Raḥmān Muḥammad 'Uthmān (al-Madīnah al-Munawwarah: al-Maktabah al-Salafiyyah, 1968), 159-160.

17 Abū Sulaymān Ḥamada bin Muhammad al-Khaț̣̄āī, Ma 'àlim al-Sunan, vol. 3 (Qāhirah: Maṭba’ah al-'Ilmiyyah, 1932), 8. 
negara terbuka luas kepada sesiapa sahaja selagi ia mempunyai akal yang sihat, meskipun dia seorang yang buta, bisu, pekak, hidung tidak sempurna, perut buncit, tidak mempunyai tangan atau kaki dia masih tetap mempunyai kelayakan untuk menjadi ketua negara. ${ }^{18}$

Pandangan serupa juga dikemukakan oleh al-Khațābi ${ }^{19}$ yang menyatakan bahawa memilih seseorang yang buta untuk menjadi ketua negara, sama sekali tidak dilarang dalam Islam. Perkara tersebut terdapat dalam beberapa riwayat hadith yang menyatakan bahawa Nabi Muhammad SAW pernah melantik 'Abd Allāh bin Ummi Maktūm menjadi ketua negara di Madinah ketika baginda hendak keluar berperang, antaranya ialah sepertimana hadith berikut:

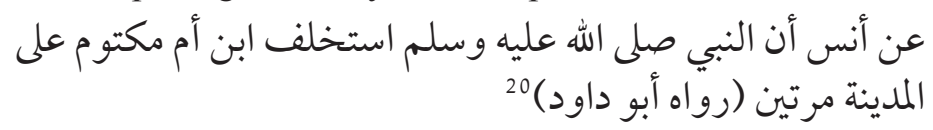

"Dari Anas sesungguhnya Nabi Muhammad SAW pernah meminta (Abdullah) Ibn Ummi Maktum (yang buta) untuk menjadi pemimpin (gabenor) Madinah sebanyak dua kali."

Berdasarkan hadith tersebut jelas menunjukan bahawa Rasulullah SAW telah melantik Ibn Ummi Maktūm untuk menggantikan baginda semasa ketiadaannya untuk mentadbir hal ehwal kenegaraan. Perlantikan tersebut berlaku bukan hanya dua kali sahaja sepertimana dalam hadith tersebut di atas, tetapi lebih daripada sepuluh kali, malah tugasan tersebut juga tidak hanya melibatkan urusan duniawi semata, malah juga ianya meliputi urusan ukhrawi, iaitu mengambil alih tugas sebagi imam sembahyang. Perkara tersebut sepertimana diriwayatkan dalam beberapa hadith berikut:

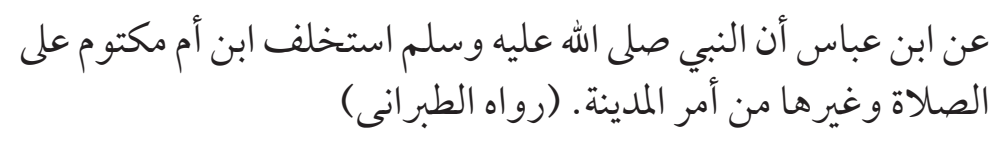

"Riwayat daripada Ibn 'Abbās bahawa Nabi SAW pernah melantik Ibn Umm Maktum di Madinah untuk menjadi Imam solat dan untuk perkara-perkara yang lainnya..." 21

18 Abū Muḥammad 'Alī bin Aḥmad Ibn Ḥazm al-Ẓāhirī, al-Faṣl fì al-Milal wa alAhwā wa al-Nihal, 11.

19 Abū Sulaymān Ḥamada bin Muḥammad al-Khațāāì, Ma 'ālim al-Sunan, 8.

20 Abī Dāwūd Sulayman Ibn al-Ash'ath al-Sajastani al-Azdi, Sunan Abī Dāwūd, vol. 2, tahqiq, Muḥammad Muḥy al-Dīn 'Abd al-Hamid (Beirūt: al-Maktabah al'Asriyyah, t.t.), 22.

21 al-Hafiz Abī al-Qāsim Sulaymān bin Aḥmad al-Tabrani, al-Mu'jam al-Kabir, vol. 4 (Qāhirah: Maktabah Ibn Taymiyyah, 1983), 256. 


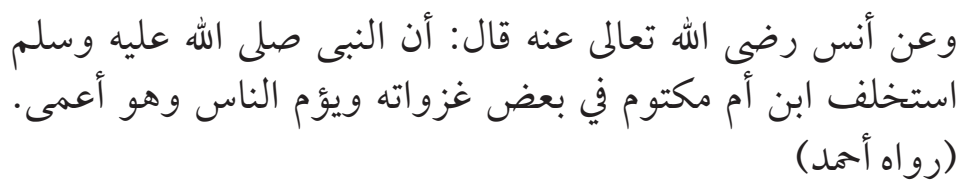

"Riwayat yang lain daripada Anas, dia berkata bahawa Nabi SAW pernah melantik Ibn Ummi Maktūm seorang yang buta untuk menjadi imam solat pada sebahagian waktunya ketika baginda keluar untuk berperang dan tugas menjadi imam bagi sembahyang berjamaah..." 22

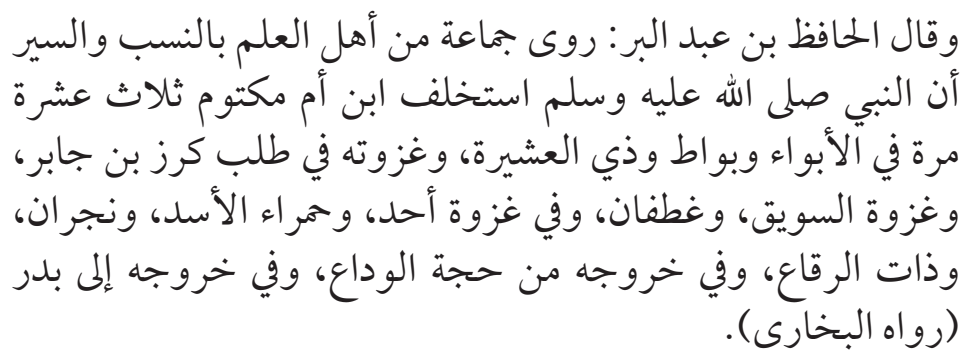

"Riwayat yang lain dari Ibn 'Abd al-Barr, beliau meriwayatkan daripada sekumpulan pakar dalam bidang geografi dan sejarah, bahawa Nabi SAW pernah melantik Ibn Umm Maktum menjadi khalifah sebanyak tiga belas kali, iaitu ketika di Abwa, di Bawwat dan di Dzil 'Ashirah serta ketika Ghazwah Thalb bin Jabir, Ghazwah al-Suwayq, Ghatfan, Uhud, Hamra al-Asad, Najran, Dzat al-Riqa dan ketika baginda keluar melakukan haji wida' dan ketika baginda keluar ke Badr..." 23

Adapun beberapa pandangan ulama tentang syarat kesihatan tersebut di atas telah penulis ringkaskannya sebagaimana jadual berikut:

22 al-Ḥāfiz Abī 'Abd Allāh Aḥmad bin Ḥanbal, Musnad Imām Aḥmad, no. 12369 (Riyāụ: Bayt al-Afkār al-Dawliyyah, 1998), 871.

23 Abū al-Faḍl Aḥmad bin 'Alī bin Muḥammad bin Aḥmad bin Hajar al-'Asqalānī, al-Iṣābah fì Tamȳ̄z al-Ṣaḥābah, vol. 4, taḥī̄q, 'Ādil Aḥmad 'Abd al-Mawjūd, et al. (Beirūt: Dār al-Kutub al-'Ilmiyyah, 1994), 496. 
Jadual 1: Pandangan Ulama Tentang Syarat Kesihatan Fizikal bagi Ketua

Negara. ${ }^{24}$

\begin{tabular}{lll}
\hline PANDANGAN & MAJORITI ULAMA & MINORITI \\
\hline
\end{tabular}

\begin{tabular}{|c|c|}
\hline & 1. al-Māwardī \\
\hline & 2. Ibn Khaldūn \\
\hline & 3. Ibn Taymiyyah \\
\hline & 4. al-Qalqashandī \\
\hline & 5. al-Mawdūdī \\
\hline Meletakkan & 6. al-Rayis \\
\hline kesihatan anggota & 7. al-Khallāf \\
\hline badan sebagai salah & 8. al-Dumayjī \\
\hline satu syarat ketua & 9. al-Marakibī \\
\hline 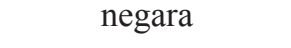 & 10. al-Qudah \\
\hline
\end{tabular}

Alasan:

Akan mengurangi dan mempengaruhi kemampuan dalam melakukan tugas sebagai ketua negara
1. Ibn Hazm
2. al-Juwayn̄̄
3. al-Baqilanī
4. al-Bayḍawī
5. al-Baghdadī

\begin{abstract}
Alasan:
Tidak terdapat dalam mana-mana nas sama ada al-Quran, al-Hadith, Ijma“ Ulama mahupun al-Qiyas yang jelas tentang larangan terhadap calon ketua negara yang mempunyai cacat fizikal.
\end{abstract}

24 Pandangan tersebut dinukil daripada beberapa kitab seperti: al-Māwardī (1989), al-Aḥkām al-Sulțāniyyah, 3; Ibn Khaldūn (2003), Muqaddimah Ibn Khaldūn,151; Ibn Taymiyyah (t.t.), al-Siyāsah al-Shar'iyyah, 17; al-Qalqashandi, (2006), Ma 'athir al-Inafah fì Ma'àlim al-Khiläfah, vol. 1, 24-25; al-Mawdūdī (1997), The Islamic Law and Constitution, 233-234; al-Rayis (1976), al-Nazariyyat al-Siyāsah al-Islāmiyyah, 287-293; Khallaf, al-Siyāsah al-Shar 'iyyah aw Niz̄ām al-Dawlah al-Islāmiyyah (Qāhirah: Dār al-Anșār, 1977), 55; al-Damuiji (1408), al-Imāmah al- 'Uzma, 261; al-Marakibi (1414), al-Khilāfah al-Islāmiyyah, 331; 'Abd al-Qādir Qudah (1981), al-Islām wa Aw ḍā'unā al-Siyāsah, 104; Ibn Hazmi al-Zāhirī (1996), al-Faṣl fì al-Milal wa al-Ahwā wa al-Nihl, vol. 5, 11; al-Juwayni (1400), Ghiyāth al-Umam fì al-Tiyāth al-Zulam, 225; al-Bāqilāni (2000), al-Inșāff, 66; al-Bayḍāwī (1991), Tawāli' al-Anwār min Mațāli'i al-Anz̄ār, 236; al-Baghdādī (1928), Ușūl al-Dìn, 277; al- Ghazālī (2001), Faḍà'ih al-Bāṭiniyyah, 162; al-Hudaybī (1977) Du'at... la Qudat, 132-133; Abū Faris (1409), al-Nizām al-Siyāsī fì al-Islām, 234; al-Jazirī (2003), Kitab al-Fiqh 'ala al-Madhhab al-Arba 'ah, vol. 5, 364; Abū Țayyib Muḥammad Shams al-Ḥaq al-'Az̄ìm Ābādī (1968), 'Awnu al-Ma 'būd, vol. 8, 159-160; Abū Sulaymān Ḥamada bin Muḥammad al-Khaț̣ābī (1932), Ma 'àlim al-Sunan, vol. 3, 8 . 


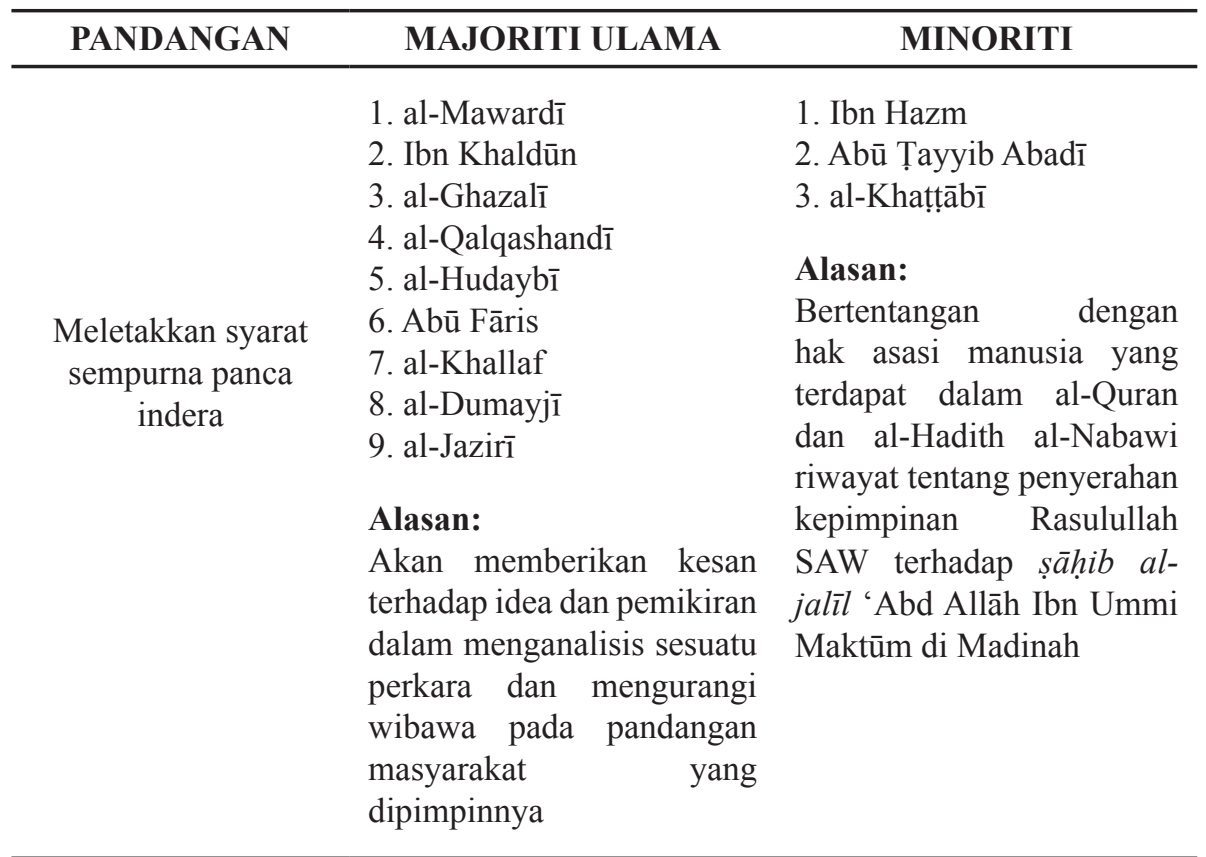

Sumber: Analisis Penyelidik.

Perbezaan ulama dalam menjadikan syarat kesihatan fizikal sebagai syarat ketua negara ialah kerana tidak terdapatnya mana-mana nas al-Quran mahupun al-Hadith yang șarīh (jelas) dan khusus tentang perkara tersebut. Nas al-Quran dan al-Hadith yang dianggap mempunyai hubungkait dengan hukum wajibnya syarat kesihatan bagi pemimpin atau ketua negara adalah sebagaimana berikut:

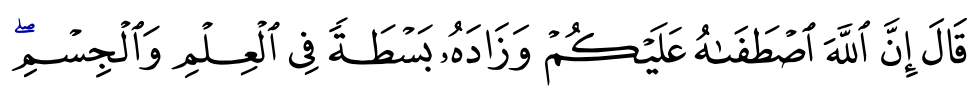

"Sesungguhnya Allah telah memilihnya menjadi raja kamu, dan telah mengurniakannya kelebihan dalam ilmu dan kegagahan tubuh."

(Surah al-Baqarah, 2: 247) 


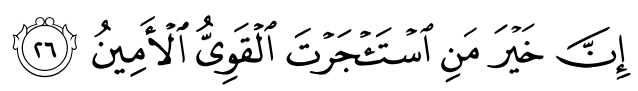

“Sesungguhnya sebaik-baik pekerja ialah yang kuat, lagi amanah..."

(Surah al-Qașaș, 28: 26)

Seterusnya hadith nabi yang diriwayatkan oleh Abū Dhar RA:25

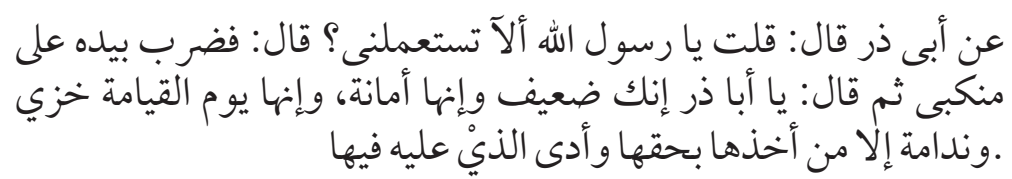

"Hadith daripada Abū Dhar berkata, saya bertanya kepada Rasulullah, mengapa engkau tidak meminta saya menyandang sebuah jawatan?" Abū Dhar berkata lagi, lalu Rasulullah menepuk bahu saya dengan tangannya sambil berkata: "Wahai Abū Dhar, sesungguhnya kamu adalah seorang yang lemah. Padahal, jawatan itu sesungguhnya adalah amanat (yang berat untuk ditunaikan) dan sesungguhnya ia pada hari kiamat nanti ditimpa kehinaan dan penyesalan, melainkan jawatan tersebut disandang oleh orang yang berkelayakan terhadapnya, dan orang yang telah menunaikan amanah dan tanggungjawab jawatannya selama tempoh ia menjawat.."

\section{AMALAN NEGARA TENTANG SYARAT KESIHATAN FIZIKAL}

Berdasarkan peruntukan perlembagaan beberapa negara terpilih seperti Amerika Syarikat, Kanada, dan United Kingdom didapati bahawa kebanyakan negara di dunia tidak mensyaratkan kesihatan fizikal bagi calon ketua negara. Ini kerana mereka berpandangan bahawa syarat tersebut dalam konteks politik semasa adalah merupakan salah satu bentuk diskriminasi terhadap hak asasi manusia. $^{26}$

Fakta sejarah membuktikan bahawa ketua negara atau presiden dari kalangan orang kurang upaya (sihat) secara fizikal terbukti mereka telah berjaya dengan

25 Imām Abī al-Ḥasan Muslim bin al-Hajjāj al-Qushayri al-Naysabūrī, Șaḥ̄h Muslim, vol. 3, Kitāb al-Imārah, Bāb Karāhah al-Imārah bi Ghayri Ḍarūrah, no. hadith 1825 (Qāhirah: Dār al-Ḥadith, 1991), 1458.

26 Curties F.J. Doebbler, International Human Right Law: Cases and Materials (Washington: CD Publishing, 2004), 387. 
cemerlang menjalankan tugasannya sebagai ketua negara. Mereka ialah seperti Franklin Roosevelt mantan Presiden Amerika bagi tempoh 1933-1945. Beliau satu-satunya Presiden yang menjawat lebih daripada dua penggal, sedangkan beliau adalah seorang yang menghidapi penyakit polio semenjak tahun 1921, iaitu sebelas tahun sebelum ia dipilih sebagai presiden. John F. Kennedy adalah juga orang yang pernah dirawat di hospital lebih kurang 30 kali dalam hidupnya kerana menderita gangguan pada tulang belakangnya semenjak beliau berumur 20 tahun. Beliau terpaksa menggunakan penyanggah tulang belakang ketika menjadi presiden dan berjaya memerintah Amerika di atas kerusi roda. Ronald Reagan pula menghidap barah usus dan masalah pendengaran dan beliau disahkan menggunakan alat bantu pendengaran. ${ }^{27}$ Manakala contoh realiti dalam konteks politik Indonesia ialah Abdurrahman Wahid atau dikenali dengan Gus Dur, beliau telah dipilih menjadi Presiden RI keempat yang mempunyai masalah kecacatan mata. Meskipun di tengah kepimpinannya beliau diberhentikan, pemecatannya bukan kerana isu beliau tidak mampu mentadbir negara, tetapi atas sebab motif politik tertentu.

Adapun negara-negara yang mensyaratkan kesihatan fizikal di dalam perlembagaan mereka antaranya ialah Negara Republik Filipina, syarat tersebut terdapat dalam The 1987 Constitution of The Republic of The Philippines, Article VII, Section 2 of the 1987:

"No person may be elected President unless he is an ..... able to read and write.." 28

Negara Republik Persekutuan Somalia dalam The Constitution of The Republic of Somaliland, Chapter 3 Article 81 (4):

"To be elected as President or Vice-President, a person must fulfil the following conditions: ..... (4). He must be physically and mentally fit to fulfil his duties",

dan di dalam artikel 37 (2) perlembagaan negara Republik Kesatuan Tanzania menyebutkan bahawa:

"Where the Cabinet finds that the President is unable to discharge the functions of his office by reason of physical or mental infirmity, it may submit to the Chief Justice a resolution requesting him to

27 Robert E. Gilbert, 'Presidential Disability And The Twentyfifth Amendment: The Difficulties Posed By Psychological Illness', Wordham Law Review, 79/1 (Dec 2010): 848 - 855; http://id.wikipedia.org/wiki/Daftar_Presiden_Amerika_Serikat 23 Januari 2014.

28 "Able to read and write" di tafsirkan sebagai seorang yang sihat panca indera sehingga dia mempunyai kemampuan untuk membaca dan menulis tanpa menggunakan alat bantu apa pun. 
certify that the President by reason of physical or mental infirmity, is unable to discharge the functions of his office."

Adapun senarai beberapa negara yang menguatkuasakan syarat kesihatan tersebut di atas telah penulis ringkaskannya sebagaimana jadual berikut:

Jadual 2: Senarai Beberapa Negara Yang Menguatkuasakan Syarat Kesihatan Fizikal.

\begin{tabular}{|c|c|c|}
\hline $\begin{array}{c}\text { NAMA } \\
\text { NEGARA }\end{array}$ & KLAUSA AYAT & KETERANGAN \\
\hline Tanzania & $\begin{array}{l}\text { Where the Cabinet finds that the } \\
\text { President is unable to discharge the } \\
\text { functions of his office by reason of } \\
\text { physical or mental infirmity.... }\end{array}$ & $\begin{array}{l}\text { Artikel } 37(2) \\
\text { Perlembagaan negara } \\
\text { Republik Kesatuan } \\
\text { Tanzania }\end{array}$ \\
\hline Somalia & $\begin{array}{l}\text { To be elected as President or Vice- } \\
\text { President, a person must fulfil the } \\
\text { following conditions: ..... (4). He } \\
\text { must be physically and mentally fit to } \\
\text { fulfil his duties }\end{array}$ & $\begin{array}{l}\text { The Constitution of The } \\
\text { Republic of Somaliland, } \\
\text { Chapter } 3 \text { Article } 81 \text { (4) }\end{array}$ \\
\hline Malaysia & $\begin{array}{l}\text { MajlisRaja-Rajamengambilketetapan } \\
\text { melalui undi sulit bahawa Raja itu } \\
\text { tidak sesuai untuk menjalankan fungsi } \\
\text { Yang di-Pertuan Agong disebabkan } \\
\text { oleh kelemahan akal atau tubuhnya, } \\
\text { atau kerana apa-apa sebab lain }\end{array}$ & $\begin{array}{l}\text { Jadual Ketiga, Bahagian } \\
\text { I (c) Undang-Undang } \\
\text { Malaysia, Perlembagaan } \\
\text { Persekutuan }\end{array}$ \\
\hline Indonesia & $\begin{array}{l}\text { Calon ketua negara atau presiden } \\
\text { mestilah "Mampu secara rohani dan } \\
\text { jasmani untuk melaksanakan tugas } \\
\text { dan kewajipannya sebagai Presiden } \\
\text { dan Wakil Presiden" }\end{array}$ & $\begin{array}{l}\text { Undang-Undang Pilihan } \\
\text { Raya Presiden (UU } \\
\text { Pilpres) No. } 23 \text { Tahun } \\
2003 \text { artikel } 6 \text { (d) }\end{array}$ \\
\hline Filipina & $\begin{array}{l}\text { No person may be elected President } \\
\text { unless he is an ..... able to read and } \\
\text { write }\end{array}$ & $\begin{array}{l}\text { The } 1987 \text { Constitution } \\
\text { of The Republic of The } \\
\text { Philippines, Article VII, } \\
\text { Section } 2 \text { of the } 1987\end{array}$ \\
\hline
\end{tabular}

Nota: UU Pilpres di Indonesia. ${ }^{29}$

Sumber: Analisis Penyelidik.

29 UU tersebut sekarang telah mengalami perubahan menjadi UU Pilpres No 42 Tahun 2008 


\section{PERUNTUKAN UNDANG-UNDANG DAN REALITI ISU SYARAT KESIHATAN KETUA NEGARA DI INDONESIA}

Adapun syarat-syarat ketua negara dalam konteks Indonesia, bermula selepas berakhirnya rejim Orde Baru (ORBA) telah diatur dalam perlembagaan negara atau Undang-Undang Republik Indonesia Nombor 23 Tahun 2003 Tentang Pilihan Raya Presiden dan Timbalan Presiden dikenali dengan Undang-Undang (UU) Pilpres No 23 Tahun 2003. Perkara yang berhubungkait dengan syarat kesihatan fizikal terdapat pada Bab II Artikel 6 (d). Peruntukan tersebut telah mendapat sokongan majoriti parti politik di Indonesia, sama ada parti yang berasaskan Islam seperti Parti Keadilan Sejahtera (PKS), Parti Persatuan Pembangunan (PPP) dan parti yang berasaskan massa Islam seperti Parti Amanat Nasional (PAN) dan yang lainnya, mahupun parti nasionalis seperti Parti Hati Nurani Rakyat (HANURA), Parti Gerakan Indonesia Raya (Gerindra), Parti Keadilan dan Persatuan Indonesia (PKPI) dan yang lainnya bersetuju terhadap peruntukan syarat kesihatan fizikal bagi calon ketua negara atau presiden di Indonesia. Ini kerana syarat tersebut bersifat normatif iaitu satu syarat yang sesuai standard bagi keperluan seorang ketua negara yang mempunyai tugasan yang berat dan mencabar. Bagi parti yang berasaskan Islam pula, menyatakan bahawa syarat tersebut amat sesuai dengan pandangan jumhur ulama sepertimana yang terdapat di dalam kitab-kitab karangan mereka.

Adapun parti yang membantah disyaratkannya syarat kesihatan fizikal di Indonesia ialah Parti Kebangkitan Bangsa (PKB). Kerana menurutnya ketua negara adalah merupakan satu jawatan awam, ${ }^{30}$ maka syarat yang lebih mustahak ialah sokongan politik atau sokongan rakyat melalui PEMILU presiden secara langsung. Bagi mereka yang bersetuju dengan PKB, berpendapat bahawa syarat moral adalah lebih penting berbanding syarat fizikal, kerana kesihatan fizikal dapat diatasi dengan kecanggihan perubatan moden, tetapi syarat moral sangat sukar untuk diatasi. Oleh yang demikian, maka jika syarat kesihatan fizikal bagi calon ketua negara tetap dipertahankan, bererti mereka telah melakukan diskriminasi dan telah melanggar hak asasi manusia terhadap orang kurang upaya (disable people). ${ }^{31}$ Kerana mereka mempunyai hak sivil dan hak politik, termasuk hak untuk memilih dan dipilih menjadi ketua negara.

Dalam konteks realiti politik Indonesia, perdebatan syarat kesihatan fizikal bagi ketua negara dipercayai timbul kerana terdapat salah seorang calon yang dikenali sebagai Gus Dur atau Abdurrahman Wahid yang mempunyai kecacatan

\footnotetext{
30 Moh. Mahfud Md., 'Menunggu Keampuhan Panwaslu,' Majalah Tempo (24-30 Mei 2004), 39.

31 Moh. Mahfud Md., 'Menunggu Keampuhan Panwaslu,' 39.
} 
mata. Kecacatan tersebut dikategorikan sebagai bentuk ketidaksesuaian calon untuk dicalonkan sebagai ketua negara, kerana bertentangan dengan syarat yang termaktub dalam undang-undang PILPRES No. 23 Tahun 2003 Artikel 6 (d) iaitu:

"Mampu secara rohani dan jasmani untuk melaksanakan tugas dan kewajiban sebagai Presiden dan Wakil Presiden."

Berdasarkan klausa tersebut, kelayakan Gus Dur sebagai calon ketua negara digagalkan oleh ahli jawatan kuasa Komisi Pemilihan Umum (KPU) atau Suruhanjaya Pilihan Raya (SPR), dengan menerbitkan surat keputusan (SK) sebagai tafsiran bagi mengesahkan ketidaklayakkan Gus Dur sebagai calon ketua negara atau Presiden Negara Republik Indonesia.

Keputusan Suruhanjaya tersebut dinilai oleh Gus Dur dan penyokongnya telah menyalahi wewenang yang sepatutnya, iaitu KPU tidak mempunyai bidang kuasa untuk mengeluarkan peraturan yang sudah jelas termaktub dalam undangundang khas pilihanraya, kerana tugas KPU hanya mengimplementasikan garis panduan yang sudah ditetapkan di dalam undang-undang Pilihan Umum Presiden (PILPRES). ${ }^{32}$ Ekoran perkara tersebut akhirnya membawa kepada berlakunya polemik, iaitu perdebatan dan perlawanan pihak Gus Dur dan para penyokongnya yang merasa haknya dinafikan. Beberapa contoh di atas membuktikan dengan nyata, bahawa syarat kesihatan fizikal wajar dipertimbangkan untuk tidak dijadikan sebagai syarat kelayakan utama bagi pengisian jawatan ketua negara. Sebaliknya, syarat kemampuan kepimpinan (leadership capability) dan sokongan politik perlu lebih dititikberatkan dalam suasana politik semasa.

Adapun ringkasan beberapa pandangan parti politik terhadap penguatkuasaan syarat kesihatan fizikal bagi ketua negara telah penulis ringkaskannya sebagaimana jadual berikut:

32 Mohd Mahfud MD, 'Menunggu Keampuhan Panwaslu,' 26. 
Jadual 3: Pandangan Parti-Parti Politik Tentang Syarat Kesihatan Fizikal di Indonesia.

\begin{tabular}{|c|c|c|}
\hline PANDANGAN & MAJORITI & MINORITI \\
\hline $\begin{array}{l}\text { Meletakkan } \\
\text { syarat } \\
\text { kemampuan } \\
\text { rohani dan } \\
\text { jasmani } \\
\text { (kesihatan } \\
\text { fizikal) }\end{array}$ & $\begin{array}{l}\text { Parti Keadilan Sejahtera } \\
\text { (PKS); Parti Amanat Nasional } \\
\text { (PAN); Parti Bulan Bintang } \\
\text { (PBB); Parti Perswatuan } \\
\text { Pembangunan (PPP); Parti } \\
\text { Golongan Karya (GOLKAR) } \\
\text { dan lain-lain. } \\
\text { Alasan: Menurut Parti-parti } \\
\text { yang berlandaskan Islam } \\
\text { seperti (PKS), syarat tersebut } \\
\text { adalah normatif dan sesuai } \\
\text { dengan pandangan mojoriti } \\
\text { ulama; kerana ianya wajar } \\
\text { dan logik jika ingin menjadi } \\
\text { Presiden atau Wakil Presiden } \\
\text { seseorang perlu diperiksa } \\
\text { dahulu kemampuan jasmani } \\
\text { dan rohaninya (fit and proper), } \\
\text { bukan hanya kepada mereka } \\
\text { yang cacat sahaja, tetapi ia } \\
\text { berlaku kepada semua calon. }\end{array}$ & $\begin{array}{l}\text { Fraksi Parti } \\
\text { Kebangkitan Bangsa } \\
\text { (FPKB) dan Fraksi Parti } \\
\text { Demokrasi Indonesia } \\
\text { Perjuangan (FPDI) } \\
\text { Alasan: Kerana ia } \\
\text { melanggar Hak Asasi } \\
\text { Manusia (HAM) yang } \\
\text { akan mengakibatkan } \\
\text { tertutupnya hak } \\
\text { seseorang warga negara } \\
\text { untuk mencalonkan } \\
\text { diri sebagai Presiden/ } \\
\text { Wapres. dan juga } \\
\text { bertentangan dengan } \\
\text { "Declaration on the } \\
\text { Rights of Disabled } \\
\text { Person" (1975) yang } \\
\text { ditetapkan Perserikatan } \\
\text { Bangsa-Bangsa Bersatu } \\
\text { (PBB). }\end{array}$ \\
\hline
\end{tabular}

Sumber: Analisis Penyelidik.

\section{HASIL KAJIAN LITERATUR BERKAITAN KONSEP SYARAT KESIHATAN FIZIKAL BAGI KETUA NEGARA MENURUT ISLAM}

Berdasarkan analisis hasil pembacaan dari beberapa pandangan ulama mendapati bahawa:

Pertama, punca berbezaan pandangan para ulama dalam memberikan senarai syarat-syarat ketua negara yang wajib dipenuhi dikalangan mereka disebabkan antaranya faktor keadaan dan realiti semasa atau $a l-w \overline{a q q i}$ ' al-ma 'ìsh. Sehingga ada ulama yang mendetailkannya seperti al-Farābi, al-Baqilānī dan alBayḍāwī, dan ada juga yang meringkaskannya dalam dua atau lebih ke dalam satu syarat sepert Ibn Taymiyyah, Qāọ̄i 'A Abd al-Jabbār dan terdapat juga syarat 
yang disepakati dan syarat yang tidak disepakati, dan syarat kesihatan fizikal adalah merupakan salah satu contoh syarat yang tidak disepakati.

Kedua, analisis data daripada beberapa pandangan para ulama terhadap syarat-syarat ketua negara, boleh dibahagikan kepada 2 bahagian iaitu syarat yang disepakati (al-shurūt al-muttafaq 'alayhā) dan syarat yang tidak disepakati (al-shurūt al-mukhtalaf fìhā). Syarat kesihatan fizikal atau dalam bahasa fiqh sebagai salamah al-hawās wa al-a 'ḍ̄' adalah termasuk dalam syarat al-mukhtalaf atau syarat yang dipertikaikan di kalangan para ulama. Syarat lainnya yang dipertikaikan ialah syarat mampu melakukan ijtihad yang mencapai tahap sebagai mujtahid (bulūgh 'alā martabah al-mujtahid) dan syarat keturunan puak Quraysh (al-nasb al-qurayshī). Adapun al-shurūt almuttafaq 'alayhā ialah Islam, mukallaf, merdeka, lelaki, adil dan mempunyai kebijaksanaan yang tinggi untuk mengurus dan mentadbir sesebuah negara.

Ketiga, syarat kesihatan fizikal telah dijadikan syarat kemestian bagi ketua negara oleh majoriti fuqaha, kerana melihat kepada tugas dan kedudukannya yang tinggi bagi mentadbir dan menguruskan hal ehwal orang ramai yang memerlukan kesejahteraan alat panca indera dan kesempurnaan anggota badan, mereka terdiri daripada al-Māwardi, Abū Ya'la, Ibn Khaldūn, al-Qalqashand̄̄ dan yang lainnya. Manakala segelintir ulama seperti Ibn Hazm dan al-Khattāāī tidak mensyaratkan atas alasan ia bertentangan dengan hak asasi dan kebebasan untuk terlibat dalam politik sebagai calon ketua negara.

Keempat, kesemua ulama bersetuju bahawa mewujudkan ketua negara adalah suatu kewajipan dan penekanan utama mesti diberi kepada kriteria kualiti keperibadian seperti adil, bijaksana, tegas dan berani. Kelima, oleh kerana terdapat perselisihan pandangan dari segelintir ulama tentang syarat kesihatan fizikal sebagai syarat menjadi ketua negara dan faktor perselisihan dan perbezaan pandangan terhadap syarat-syarat ketua negara, telah membuat ruang untuk berijtihad dalam pemakaiannya berdasarkan keperluan dan realiti setempat. Ini selaras dengan kaedah fiqh yang menyebutkan:

$$
\text { لا ينكر تغيّر الأحكام الإجتهاديّة بتغيّر الأزمان }
$$

\section{"Perubahan hukum tidak dapat dinafikan dengan terdapatnya perubahan-perubahan masa." 33}

Kaedah tersebut menegaskan bahawa yang dimaksud 'hukum' atau ketetapan (dalam konteks kajian ini ialah hukum penetapan syarat ketua negara) adalah merupakan bentuk hukum ijtihadi yang berasaskan kepada kemaslahatan semasa. Kerana hukum asal yang ditetapkan oleh nas tidak

33 Muḥammad Șidqi bin Aḥmad bin Muḥammad al-Būrnū, al-Wajīz fì Ị̇āh Qawā ‘d al-Fiqh al-Kuliyyah, vol. 4 (Beirūt: Mu'assasah al-Risālah, 1996), 312. 
berubah, tetapi yang mungkin berubah hanya hukum-hukum cabang yang bersifat interpretatif yang tidak disebutkan secara definitif dan spesifik dalam al-Quran mahupun al-Hadith al-Nabawi.

Keenam, ulama-ulama kontemporari banyak menggunakan kaedah tersebut dalam menentukan sebuah hukum yang terdapat perbezaan pandangan dengan mengambil kira kesesuaiannya dalam pemakaian semasa, seperti pandangan al-Shātibī tentang kriteria menentukan sifat adil bagi para saksi, dan Prof. Dr. Yūsuf al-Qaraḍāwī dalam memutuskan pandangannya berkenaan perkara nasikh dan mansukh dalam surah al-Anfāl ayat 65 dan 66, dan masalah zakat fitrah serta beberapa perkara yang lainnya seperti perkara yang berhubungkait dengan perubahan tempat, perubahan zaman, keadaan, adat resam, informasi, keperluan manusia, kemampuan manusia dan teknologi, kebiasaan umum, keadaan sosial masyarakat, ekonomi dan politik, dan perubahan pandangan dan pemikiran.

\section{HASIL KAJIAN LITERATUR BERKAITAN PEMAKAIAN SYARAT KESIHATAN FIZIKAL BAGI KETUA NEGARA DI INDONESIA}

Pertama, syarat-syarat ketua negara dalam konteks politik Indonesia terdapat dua puluh persyaratan dalam Undang-Undang Pemilu No. 23 Tahun 2003. Dua puluh persyaratan tersebut didapati di dalamnya ada tiga persyaratan yang membawa kepada kontroversi, salah satunya ialah syarat kesihatan fizikal yang berbunyi:

\section{"Mampu secara rohani dan jasmani untuk melaksanakan tugas dan kewajiban sebagai Presiden dan Wakil Presiden."}

Berdasarkan hasil rundingan di antara sesama perwakilan parti di parlimen, pada peringkat perlembagaan ketiga-tiga syarat kontroversi tersebut dapat diterima berdasarkan kepada penyelesaian menang-menang (win-win solution). Tetapi pada pelaksanaannya Komisi Pemilihan Umum (KPU) atau Suruhanjaya Pilihan Raya (SPR) telah mengeluarkan SK. No. 26 Tahun 2004, sehingga akhirnya membawa natijah kepada kegagalan Gus Dur menjadi calon Presiden.

Kedua, Isu-isu syarat kesihatan calon ketua negara atau presiden hanya ramai diperkatakan dan diperdebatkan semasa pilihan raya tahun 2004 dan 2009 sahaja, kerana objek sasarannya ketika itu ialah Gus Dur. Iaitu orang yang terbabit secara langsung dengan syarat tersebut. Ini menunjukan bahawa syarat ini hanya dibahaskan apabila terdapat salah seorang calon ketua negara mengalami kecacatan fizikal. 
Ketiga, berpolitik ialah salah satu hak asasi manusia yang dijamin dan dilindungi oleh kebanyakan perundangan. Begitu juga ia terjamin dalam alQuran melalui ayat-ayat tentang persamaan hak dan kebebasan sebagaimana yang berikut:

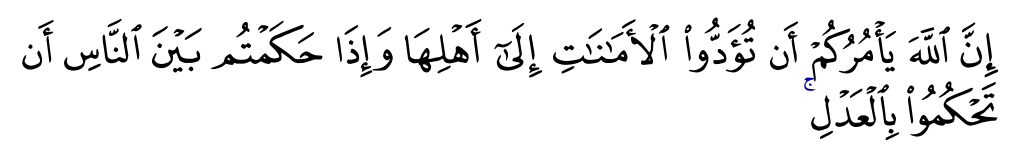

"Sesungguhnya Allah menyuruh kamu supaya menyerahkan segala amanah kepada ahlinya, dan apabila kamu menjalankan hukum di antara manusia, supaya kamu menghukum dengan adil..."

(Surah al-Nisā' 4: 58)

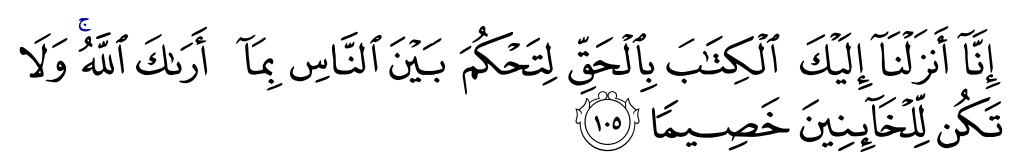

"Sesungguhnya Kami menurunkan kepadamu Kitab (al-Quran) dengan membawa kebenaran, supaya engkau menghukum di antara manusia menurut apa yang Allah telah tunjukkan kepadamu melalui wahyu-Nya; dan janganlah engkau menjadi pembela bagi orang yang khianat..."

(Surah al-Nisā' 4: 105)

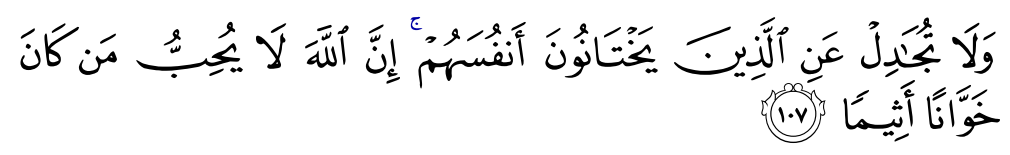

"Dan janganlah engkau berbahas untuk membela orang yang khianati dirinya sendiri. Sesungguhnya Allah tidak suka orang yang berkhianat, lagi berdosa..."

(Surah al-Nisā’ 4: 107) 


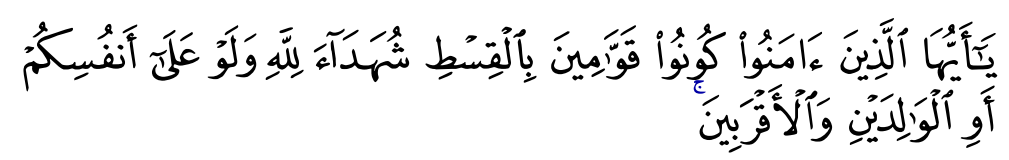

"Wahai orang yang beriman! Hendaklah kamu menjadi orang yang sentiasa menegakkan keadilan, lagi menjadi saksi kerana Allah, sekalipun terhadap diri kamu sendiri, atau ibu bapa dan kaum kerabat kamu..."

(Surah al-Nisā' 4: 135)

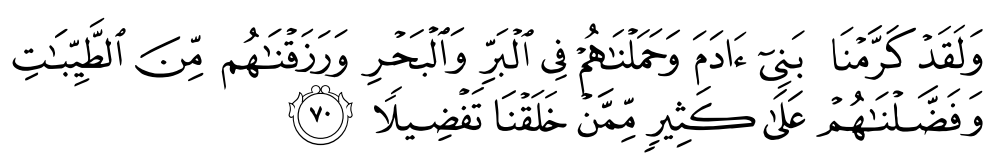

"Dan sesungguhnya Kami telah memuliakan anak-anak Adam; dan Kami telah beri mereka menggunakan kenderaan di darat dan di laut; dan Kami berikan rezeki kepada mereka dari yang baik-baik serta Kami telah lebihkan mereka atas kebanyakan makhluk yang telah Kami ciptakan"

(Surah al-Isrā' 17: 70)

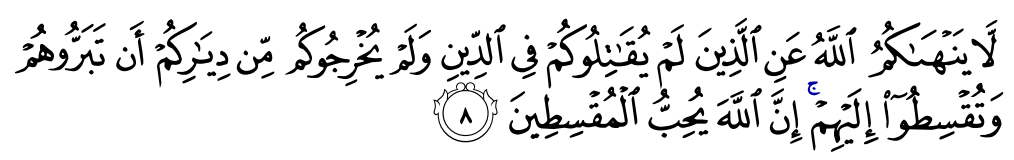

"Allah tidak melarang kamu daripada berbuat baik dan berlaku adil kepada orang-orang yang tidak memerangi kamu kerana agamamu, dan tidak mengeluarkan kamu dari kampung halaman kamu; sesungguhnya Allah mengasihi orang yang berlaku adil",

(Surah al-Mumtahanah, 70: 8)

Adapun jaminan hak berpolitik di dalam perlembagaan dan resolusi negara Indonesia antara lain termaktub di dalam UU RI No. 39 Tahun 1999 Tentang Hak Asasi Manusia ${ }^{34}$ dan UU RI No. 19 Tahun 2011 Tentang Pengesahan konvensi mengenai hak-hak penyandang disabilitas, (Convention on the rights of persons with disabilities), ${ }^{35}$ United Nations Universal Declaration

34 Fakultas Hukum Universitas Sam Ratulangi, 'UU RI No. 39 Tahun 1999, Hak Asasi Manusia,' http://hukum.unsrat.ac.id/uu/uu_39_99.htm, dicapai pada 12 Februari 2014.

35 Advocacy Toolkit, 'Convention on the Rights of Persons with Disabilities, United Nations Human Rights,' http://www.ohchr.org/Documents/Publications/ AdvocacyTool_en.pdf, dicapai pada 15 Mac 2014. 
of Human Rights 1948, ${ }^{36}$ Declaration on the Rights of Disable Persons 1975, ${ }^{37}$ The Cairo declaration on human rights in Islam $1990^{38}$ dan International Covenant on Civil and Political Rights. ${ }^{39}$

Keempat, hukum Islam terbahagi kepada al-thābit wa al-mutaghayyir. Al-thābit ialah hukum yang tetap dan solid tidak boleh diubah seperti yang berhubungkait dengan ibadah khusus (mahdah) seperti jumlah bilangan rakaat dalam sembahyang lima waktu. Adapun al-mutaghayyir ialah hukum yang boleh berubah dan diubah sejalan dengan persekitaran dan perkembangan serta realiti politik semasa, jenis hukum ini lebih berhubungkait dengan perkaraperkara $m u$ 'àmalah, seperti permasalahan politik dan pemerintahan.

Kelima, menurut Dr. Kamāl Habīb, sumber asas ijtihad politik adalah realiti kehidupan semasa (al-wāqi 'al-ma 'īsh), dan tujuan asasnya ialah menyelesaikan segala permasalahan dan kesukaran terhadap isu-isu politik semasa. ${ }^{40}$ Adapun kaedah yang digunakan adalah berdasarkan kepada mașlahah mursalah demi untuk kepentingan rakyat yang dirasakannya baik dan tidak bercanggah dengan Syariah walaupun ia tidak berdasarkan kepada sesuatu nas secara khusus.

Keenam, tiada keperluan bertaqlid kepada syarat kesihatan yang telah dikemukakan oleh para ulama, kerana syarat tersebut juga merupakan hasil ijtihad mereka berdasarkan kepada keperluan semasa. Oleh yang demikian, maka mana-mana calon ketua negara yang mempunyai kekurangan dari aspek fizikal, tetapi mempunyai kemampuan untuk memimpin secara adil dan dapat mensejahterakan rakyatnya tidak patut diketepikan haknya untuk menjadi ketua negara dalam konteks politik Indonesia.

36 United Nations (UN), 'United Nations Universal Declaration of Human Rights 1948,' Watch List on Children and Armed Conflict, http://watchlist.org/wordpress/ wp-content /uploads/Universal-declaration-of-human-rights.pdf, dicapai pada 23 Mac 2014

37 Max-Planck-Institute 'Declaration on the Rights of Disabled Persons,' http://www. mpil.de/files/pdf2/declaration_on_the_rights_of_disabled_persons.pdf, dicapai pada 20 April 2014.

38 Organization of Islamic Cooperation, 'The Cairo Declaration on Human Rights in Islam,' http://www.oic-oci.org/english/article/human.htm, dicapai pada 3 Mei 2014.

39 Human Rights Treaty Monitoring Coordination Center (HRTMCC), 'International Covenant on Civil and Political Rights, Centre for Civil and Political Right,' http:// www.ccprcentre.org/doc/2014/02/INT_CCPR_NGO_NPL_14741_E.pdf, dicapai pada 23 Januari 2014.

40 Kamal Habib, 'F̄̄ al-Ijtihād al-Siyāsī', elsharq, http://elsharq.tv/node/66390, dicapai pada 31 Mac 2014. 


\section{KESIMPULAN}

Berdasarkan huraian di atas, dapat disimpulkan bahawa syarat kesihatan fizikal merupakan bentuk syarat bagi kesempurnaan calon ketua negara, bukan syarat kemestian yang perlu dimiliki oleh setiap calon, kerana apa yang terpenting bagi calon ketua negara ialah kemampuan dalam kepimpinan, kemampuan melaksanakan keadilan secara menyeluruh, dan mendapat sokongan padu dari rakyat yang akan dipimpinnya. Syarat kesihatan bagi ketua negara untuk konteks masa sekarang tidak perlu dikuatkuasakan melalui akta mahupun perlembagaan, tetapi ia boleh dijadikan sebagai syarat yang tidak tertulis, bagi membuka peluang dan memenuhi kepentingan hak asasi untuk mencapai keadilan kepada semua iaitu calon dan rakyat. Oleh itu, penulisan ini mencadangkan supaya memperhalusi semula pandangan Ibn Hazm sebagai rujukan, khasnya dalam konteks politik di Indonesia.

Dalam sistem demokrasi di Indonesia Komisi (suruhanjaya) Pemilihan Umum (KPU) sebagai badan pelaksana pilihan raya umum, sepatutnya tidak perlu mengeluarkan peraturan yang berlawanan dengan UUD 1945 dan UU Pilpres yang sudah sedia ada, agar tidak berlaku pertindihan dan percanggahan syarat dan peraturan, sehingga pada masa yang sama tidak terdapat mana-mana pihak atau individu yang merasa diperlakukan secara tidak adil. Perlaksanaan demokrasi yang telah berlangsung beberapa dekad ini, menunjukan bahawa rakyat sudah semakin bijak memilih calon pemimpinnya sendiri, hak pilih ketua negara mutlak berada di tangan rakyat, maka biarkan rakyat yang memberikan penilaian bagi menentukan pilihannya sendiri. Oleh kerana itu, sewajarnya kita mempunyai sifat lapang dada terhadap timbulnya setiap perbezaan pandangan para ulama tentang sesuatu perkara yang berhubungkait dengan isu syarat kesihatan fizikal bagi ketua negara, sehingga setiap perbezaan pandangan yang timbul akan membawa kepada rahmat, bukan menjadi bencana bagi rakyat Indonesia khasnya, dan masyarakat Islam amnya.

\section{RUJUKAN}

Ābādī, Abū Ṭayyib Muḥammad Shams al-Haq al-'Aẓ̄im, 'Awn al-Ma 'būd, vol. 8, taḥqīq, 'Abd al-Raḥmān Muḥammad 'Uthmān (al-Madīnah alMunawwarah: al-Maktabah al-Salafiyyah, 1968).

'Abd al-Qādir Qūḍah, al-Islām wa Awḍ̂̄'unā al-Siyāsah (Beirūt: Mu'assasah al-Risālah, 1981).

'Alī 'Abd al-Wahid Wafi, al-Madīnah al-Fadilah li al-Farabī (Qāhirah: Nahdah Misr, t.t.) 
Abū Fāris, Muḥammad 'Abd al-Qādir, al-Niz̄ām al-Siyāsī fì al-Islām (Jordan: Dar al-Furqan, 1409).

Advocacy Toolkit, 'Convention on the Rights of Persons with Disabilities, United Nations Human Rights,' http://www.ohchr.org/Documents/ Publications/AdvocacyTool_en.pdf, dicapai pada 15 Mac 2014.

Aḥmad bin Hanbal, Musnad Imām Ahmad bin Hanbal, vol. 10, no. hadith 12530 (Beirut: Mu'assasah al-Risālah, 1996).

al-'Ash'ārī, Abū al-Hasan 'Alī bin Ismā'īl, Maqālāt al-Islāmiyyīn wa alIkhtilāf al-Mușallīn, vol. 2 (Beirūt: Maktabah al-'Așriyyah, 1990).

al-'Asqalānī, Abū al-Faḍl Aḥmad bin 'Alī bin Muhammad bin Aḥmad bin Hajar, al-Ișābah fī Tamyīz al-Șaḥābah, vol. 4, taḥqīq, 'Ādil Aḥmad 'Abd al-Mawjūd, et al. (Beirūt: Dār al-Kutub al-'Ilmiyyah, 1994).

al-Bāqilānī, al-Qāội Abī Bakr bin al-Ṭayyib, al-Inșāff (Mișr: al-Maktabah alAzhariyyah li al-Turāth, 2000).

al-Bayḍāwī, al-Qāḍ̄̄ Nāṣir al-Dīn Abū al-Khayr 'Abd Allāh bin 'Umar, Tawāli' al-Anwār min Maṭāli’i al-Anzā̄r (Beirūt: Dār al-Jayl, 1991).

al-Baghdādī, Abī Manșūr 'Abd al-Qāhir bin Țāhir, Ușūl al-Dīn (Istanbul: Maṭa'ah al-Dawlah, 1928).

al-Būrnū, Muḥammad Șidqī bin Aḥmad bin Muḥammad, al-Wajīz fì Iḍāh Qawā'id al-Fiqh al-Kuliyyah (Beirūt: Mu'assasah al-Risālah, 1996).

al-Damījī', 'Abd Allāh bin 'Umar bin Sulaymān, al-Imāmah al-'Uzmā 'Inda Ahl al-Sunnah wa al-Jamā' 'ah (Riyāḍ: Dār al-Ṭayyibah, 1987).

Fakultas Hukum Universitas Sam Ratulangi, 'UU RI No. 39 Tahun 1999, Hak Asasi Manusia,' http://hukum.unsrat.ac.id/uu/uu_39_99.htm, dicapai pada 12 Februari 2014.

al-Ghazālī, Abū Hāmid Muḥammad bin Muhammad bin Muhammad, alIqtiṣād wa al-I’tiqād (Dimasq: al-Ḥikmah L̄̄ al-Ṭibā'ah wa al-Nashr, 1994).

al-Ghazālī, Abū Hāāmid Muhammad bin Muhammad bin Muhammad, Faḍā'ih al-Bāṭiniyyah (Beirūt: al-Maktabah al-'Asriyyah, 2001).

al-Huḍaybī, Hasan Ismā'îl, Du 'āt la Quḍ̂ah (Qāhirah: Dār al-Ṭiba'ah wa alNashr al-Islāmiyyah, 1977).

Human Rights Treaty Monitoring Coordination Center (HRTMCC), 'International Covenant on Civil and Political Rights, Centre for Civil and Political Right,' http://www.ccprcentre.org/doc/2014/02/INT_ CCPR_NGO_NPL_14741_E.pdf, dicapai pada 23 Januari 2014. 
Ibn Khaldūn, 'Abd al-Raḥmān, Muqaddimah Ibn Khaldūn: al-Musammā bì al-Kitāb al-'Ibar wa al-'Ajam wa al-Barbar wa Man 'Asrāruhum Min Daw'i al-Sulțān al-Akhbār (Beirūt: Dār al-Kutub al-'Ilmiyyah, 2003).

Ibn Hazm, al-Imām Abī Muḥammad 'Alī bin Aḥmad al-Z̄āhirī, al-Faṣl fì alMilal wa al-Ahwā wa al-Nihal, vol. 5, taḥqīq, Muḥammad Ibrāhīm Naṣr et al. (Beirūt: Dār al-Jayl, 1996).

Ibn Ab̄̄ al-Rabi', Shihāb al-Dīn Aḥmad bin Muḥammad, Suluk al-Mālik fi Tadbir al-Mamālik, tahqiq, 'Arif Ahmad 'Abd al-Ghan̄̄ (Syria: Dār Kannan, 1996).

Ibn Taymiyyah, Shaykh al-Islām Aḥmad bin 'Abd al-Halīm bin 'Abd al-Salām,

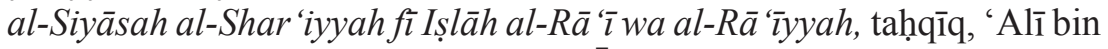
Muḥammad al-'Umrān (Jeddah: Dār 'Ālam al-Fawā'id, 1983).

al-Jaz̄īī, 'Abd al-Raḥmān, al-Fiqh 'alā al-Madhāhib al-Arba'ah, vol. 5 (Beirūt: Dār al-Kutub al-Ilmiyyah, 2003).

al-Juwaynī, Imām al-Haramayn Abī al-Ma‘āli, Ghiyāth al-Umam fì al-Tìāth al-Zulam, taḥiq, Mustafa Hilmi, et al. (Iskandariyah: Dār al-Da'wah, '1979).

Kamāl Habīb, 'F̄̄ al-Ijtihād al-Siyās̄̄', elsharq, http://elsharq.tv/node/66390, dicapai pada 31 Mac 2014.

al-Khațtābī, Abū Sulaymān Hamada bin Muhammad, Ma 'àlim al-Sunan, vol. 3 (Qāhirah: Mațba'ah al-'Ilmiyyah, 1932).

Khallāf, 'Abd al-Wahhāb, al-Siyāsah al-Shar 'iyyah aw Nizam al-Dawlah alIslāmiyyah fì al-Shū'un al-Dusturiyah wa al-Kharijiyyah wa al-Māliyah (Qāhirah: Dār al-Anșār, 1977).

al-Māwardī, Abū Ḥasan 'Alī bin Muḥammad bin Habīb al-Bașri, al-Aḥkām al-Sulțāniyah wa al-Wilayāt al-Dīniyyah, taḥqīq. Dr. Aḥmad Mubārak al-Baghdādi (Kuwayt: Maktabah Dār Ibn Qutaybah, 1989).

Max-Planck-Institute 'Declaration on the Rights of Disabled Persons,' http:// www.mpil.de/files/pdf2/declaration_on_the_rights_of_disabled_ persons.pdf, dicapai pada 20 April $201 \overline{4}$.

Muḥammad Ra'fat 'Uthmān, Riyāsah al-Dawlah fì al-Fiqh al-Islāmī (Qāhirah: Dār al-Kitāb al-Jami'‘̄, 1975).

al-Marākib̄̄, Jamāl Aḥmad al-Sayyid Jād, al-Khilāfah al-Islāmiyyah Bayna Nuzum al-Hukm al-Mu 'ạșirah (Qāhirah: Jamā'ah Anșār al-Sunnah alMuhammadiyyah, Idārah al-Da'wah wa al-I'lām, Lajnah al-Bahth al'Ilmī, 1414).

al-Mawdūd̄̄, Abū al-A'lā, The Islamic Law and Constitution (Lahore: Islamic Publication Ltd., 1997). 
Mohd. Mahfud MD, 'Menunggu Keampuhan Panwaslu,' dalam Kolom Majalah Kompas, 24-30 (Mei 2004).

al-Naysabūrī, Imām Abī al-Hasan Muslim bin al-Hajjāj al-Qushayrī, Ṣahīh Muslim, vol. 3, Kitāb al-Imārah (Qāhirah: Dār al-Hadīth, 1991).

Organization of Islamic Cooperation, 'The Cairo Declaration on Human Rights in Islam,' http://www.oic-oci.org/english/article/human.htm, dicapai pada 3 Mei 2014.

al-Qurțubī, Abī̄ 'Abd Allāh Muḥammad bin Aḥmad bin Abī Bakr, al-Jāmi ‘ l̄̄ Ahkām al-Qur' ān, taḥqiq, Dr. 'Abd Allāh bin 'Abd al-Muḥsin al-Turkī, vol. 1 (Beirūt: Mu’assasah al-Risālah, 2006).

al-Qalqashandī, Abū al-'Abbās Aḥmad bin 'Abd Allāh, Ma'āthir al-Ināfah fì Ma'ālim al-Khilāfah, vol. 1, taḥqīq, 'Abd al-Sattār Aḥmad Farrāj (Lubnān: 'Ālam al-Kutub, 2006).

al-Rais, Muḥammad Ḍiyā al-Dīn, al-Nazariyyāt al-Siyāsiyyah al-Islāmiyyah (Qāhirah: Maktabah Dār al-Turāth, 1976).

Robert E. Gilbert, 'Presidential Disability and the Twentyfifth Amendment: The Difficulties Posed By Psychological Illness,' Wordham Law Review, 79/1 (2010): 848-855; http://id.wikipedia.org/wiki/Daftar_Presiden_ Amerika_Serikat 23 Januari 2.

al-Shawkān̄̄, Muḥammad bin 'Al̄̄ bin Muhammad, Nayl al-Awțār Sharh Muntaqā al-Akhbār, vol. 8 (Mișr: Maktabah wa Maṭba'ah Mușțafā alBābī al-Ḥalabī wa Awlāduh, t.t.).

United Nations (UN), 'United Nations Universal Declaration of Human Rights 1948,' Watch List on Children and Armed Conflict, http://watchlist.org/ wordpress/wp-content/uploads/Universal-declaration-of-human-rights. pdf, dicapai pada 23 Mac 2014. 
Jurnal Syariah, Jil. 23, Bil. 3 (2015) 377-400 